JOURNAL OF SECURITY AND SUSTAINABILITY ISSUES

ISSN 2029-7017 print/ISSN 2029-7025 online

2019 June Volume 8 Number 4

http://doi.org/10.9770/jssi.2019.8.4(7)

Scopus

\title{
THE INFLUENCE OF THE GLOBAL TECHNOLOGICAL CHANGES ON PRINCIPLES AND FUNCTIONS OF ACCOUNTING AND FORMATION OF THE ORGANIZATION STRATEGY
}

\author{
Volodymyr Osmyatchenko ${ }^{1}$, Viktoriia Oliinyk ${ }^{2}$, Olexandra Mazina ${ }^{3}$, Natalia Matselyukh ${ }^{4}$, Valerii Ilin $^{5}$, Artur Orzel $^{6}$ \\ 1,2,3,4,5 Department of Accounting, Educational and Scientific Institute of Accounting, Analysis and Audit, \\ University of the State Fiscal Service of Ukraine, Irpin, Ukraine, \\ ${ }^{6}$ Faculty of Economics and Legal Sciences, Kazimierz Pulaski University of Technology and Humanities in Radom, Poland
}

Emails: ${ }^{1}$ osssa@i.ua (correspondingauthor)

Received 15 November 2018; accepted 10 April 2019; published 30 June 2019

\begin{abstract}
The article reveals the role of modern information technologies in the accounting system. Features of transformation of accounting principles and functions in conditions of their application are considered. The special feature technical-technological development is cyclisity. Every technological cycle is characterized by the revolution and the existence of the leading sectors of economy. The types of computer information technology and economic problems in the context of technological cycles are investigated. Change in technological cycles leads to the transformation of the theory of accounting and its practical application. The development of the accounting system is increasingly directed at the creative professional judgment of experts under condition of the existence of and assumption on the polivariative approach to the choice of one or another method of presentation of information in the system. Such an approach to the selection of accounting estimates is possible in case the highly intelligent tools are present, such as the modern information systems. On the basis of statistical data, the authors prove that the use of information and communication technologies in enterprises of Ukraine is increasing year by year, in particular of cloud computing. The article investigates the place of Ukraine in the ranking according to the index of development of information and communication technologies among other countries of the world. Information systems and accounting technologies serve as a link between business activities and managers at all levels of decision-making. The authors suggest an intellectual cycle for the formation and implementation of enterprise strategy using modern global information resources, which are obtained from the use of modern information technologies with a strong intellectual potential. The prospects for the introduction of technologies of artificial intelligence, as one of the features of the sixth technological way, in accounting are revealed.
\end{abstract}

Keywords: accounting, technological changes, information technologies, enterprise strategy, creativity

Reference to this paper should be made as follows: Osmyatchenko, V.; Oliinyk, V.; Mazina, O.; Matselyukh, N.; Ilin, V.; Orzeł, A. 2019, The influence of the global technological changes on principles and functions of accounting and formation of the organization strategy, Journal of Security and Sustainability Issues, 8(4): 631-641. http://doi.org/10.9770/jssi.2019.8.4(7)

JEL Classifications: M41

\section{Introduction}

In the conditions of rapid development of modern information technologies and their use in all spheres of human activity, including in the accounting system, the approaches to solving problems of any socioeconomic processes are changing radically. Their intellectualization is on the foreground. These and other processes lead to the transformation of the accounting principles and functions and directly of the role and professional skills of the accountant. There is cyclicity in technical and technological development. Each technology cycle is characterized by the existence of technological revolution and leading sectors of the economy (Limba et al., 2018; Vegera et al. 2018). Change of technological cycles leads to the transformation of the theory of accounting and its practical application. Particularly, approaches to accounting changed due to the application of information technologies of VIth technological structure. 
Many scientists investigated technological changes and their influence over other spheres of human activity. Among them S. Glazyev (1993), who introduced a new theory of long-term technical and economic development. The theory was developed on the basis of the study of structural changes in Russia's economy. S. Yerokhin (2006) researched the technological changes and their impact on various fields of human activity. J. Jusevich (2015), Paiva \& Carvalho (2018) identified the most important current trends in accounting. G. Liakhovich (2017), Zhatkin et al. (2017), Pustylnick et al. (2017) identified the main trends in accounting development, taking into account the technological and innovation development. Faye Chua (2013), Isniawati et al. (2018) described the impact of technological trends on the accountants' profession in the world. D. Śmihula (2010) opened new views on the theory of "long waves" in terms of technological progress. However, some issues remain unsolved, in particular: the impact of information systems and new generation accounting technologies on existing accounting principles and functions and on the formation of new ones; the role of the raw data of the accounting process and modern information technologies in the formation and implementation of the enterprise strategy.

\section{An overview of the influence of technological changes on principles and functions of accounting and formation of the strategy of the enterprise}

According to Daniel Šmihula theory of cycles of technological revolutions, the main technological innovations appear not constantly, but with the help of special cycles whose time intervals are reduced due to technical progress (Šmihula, 2010). The period of time, which is characterized by the highest concentration of technological innovations, is considered as a "technological revolution" (the stage of innovation) and correlates with the phase of the beginning of economic growth. The temporary reduction of the number of new technological developments takes place, provided that new technologies are applied in practice. During this period the emphasis is made on the maximum practical implementation of existing technologies, including those in the accounting.

The application phase is associated with the period of economic growth. The next feature is markets' saturation with technological products, lowering of the profitability of new technologies to the level of that of previous generation, getting profit not higher than the average profit obtained from new capital investments. This is the beginning of the crisis, which serves as a vector of new technological research. Thus, the stages of stagnation and crisis are overcome by new technological revolution (the beginning of a new wave), which is characterized by new technologies that will revitalize the economy and will transform the accounting as a system and process (Fig. 1).

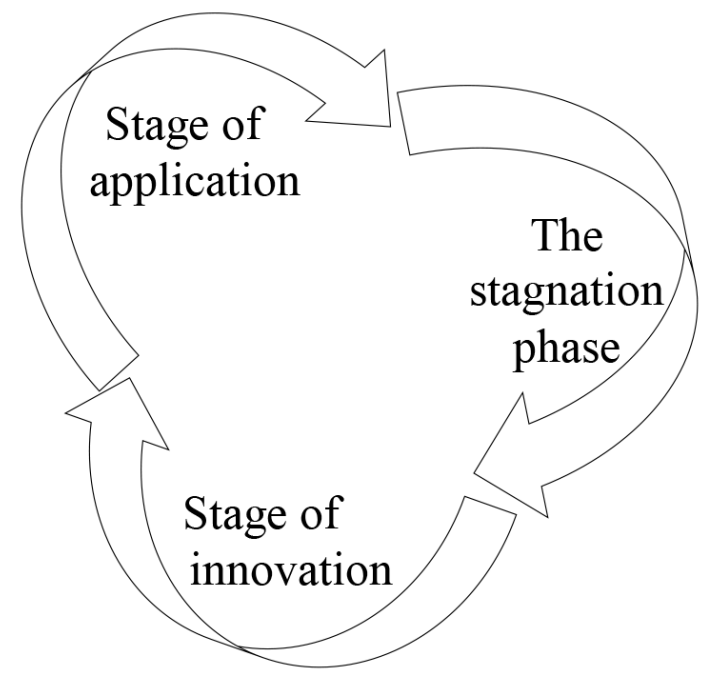

Fig. 1. The internal structure of the wave according to the theory of D. Šmihula

Source: Developed by the authors on the basis of (Šmihula, 2010)

M.M. Benko (Benko, 2010) identified the economic tasks of computer information technologies in accounting, which can be structured in the context of technological cycles (Table 1). 
Table 1. Types of Computer Information Technologies and Economic Tasks in the Context of Global Technological Cycles

\begin{tabular}{|c|c|c|c|c|}
\hline $\begin{array}{l}\frac{2}{2} \\
\frac{2}{0}\end{array}$ & ב. & $\begin{array}{l}\text { Technological } \\
\text { revolution }\end{array}$ & $\begin{array}{l}\text { Leading sectors } \\
\text { of the economy }\end{array}$ & Type of computer information technologies and economic tasks \\
\hline 1. & $\begin{array}{c}1600- \\
1740\end{array}$ & $\begin{array}{l}\text { Financial- } \\
\text { agro-cultural } \\
\text { revolution }\end{array}$ & $\begin{array}{l}\text { Finance, } \\
\text { agriculture, trade }\end{array}$ & \\
\hline 2. & $\begin{array}{c}1780- \\
1840\end{array}$ & $\begin{array}{l}\text { Industrial } \\
\text { revolution }\end{array}$ & $\begin{array}{l}\text { Textiles, iron, coal, } \\
\text { railways, canals }\end{array}$ & \\
\hline 3. & $\begin{array}{c}1880- \\
1920\end{array}$ & $\begin{array}{l}\text { Technical } \\
\text { Revolution }\end{array}$ & $\begin{array}{c}\text { Chemistry, electrical } \\
\text { engineering, } \\
\text { machine building }\end{array}$ & $\begin{array}{l}\text { Mechanized (Mechanization of individual elements of the processes of } \\
\text { accounting and management work) }\end{array}$ \\
\hline \multirow{5}{*}{4.} & \multirow{5}{*}{$\begin{array}{c}1940- \\
1970\end{array}$} & \multirow{5}{*}{$\begin{array}{l}\text { Scientific and } \\
\text { Technical Revolu- } \\
\quad \text { tion }\end{array}$} & \multirow{5}{*}{$\begin{array}{l}\text { Aviation, Nuclear } \\
\text { Industry, } \\
\text { Cosmonautics, } \\
\text { Synthetic Materials, } \\
\text { Petroleum Industry, } \\
\text { Cybernetics }\end{array}$} & $\begin{array}{l}\text { 1934- 40's - 1950's - Mechanized (Mechanization of separate areas of ac- } \\
\text { counting, work in the management system) }\end{array}$ \\
\hline & & & & $\begin{array}{l}\text { 1950-1960 Partial electronic processing of credential data. Elemental } \\
\text { Base: Electronic Lamps - 1st Generation, Semiconductor Elements - Sec- } \\
\text { ond Generation (Use of Computer Technology to Solve Certain Most } \\
\text { Complex Accounting Tasks) }\end{array}$ \\
\hline & & & & $\begin{array}{l}\text { 1960's-1970's electronic system for processing of credentials. Elemental } \\
\text { base - Integrated circuits - III generation (Electronic processing of ac- } \\
\text { counting information, storage of normative reference data in computer } \\
\text { memory, printing of machine-graphics on paper) }\end{array}$ \\
\hline & & & & $\begin{array}{l}\text { 1970's Centralized automated processing of accounting information in the } \\
\text { conditions of computing centers of collective use. Elemental base - In- } \\
\text { tegrated Circuits (Integrated processing of accounting information at all } \\
\text { stages of accounting. Comprehensive processing of current management } \\
\text { information at all stages of the management process of the enterprise, the } \\
\text { organization. The transition to the development of subsystems, automated } \\
\text { control systems }\end{array}$ \\
\hline & & & & $\begin{array}{l}\text { End of } 1970-1980 \text { 's. Specialization of technological decisions in ac- } \\
\text { counting on the basis of mini-computers, personal computers and remote } \\
\text { access to the arrays of credentials while simultaneously universalizing the } \\
\text { methods of processing accounting information on the basis of powerful } \\
\text { computers. Elemental base - chips. The emergence of programming lan- } \\
\text { guages, close to the professional languages subject areas of work (account- } \\
\text { ing). The emergence of PCs (Development of the control system (ACS } \\
\text { technological processes), automation systems, ACS enterprises, industry } \\
\text { ACS, national systems: scheduled calculations, statistics, equipment, sci- } \\
\text { ence and technology, financial calculations, etc. Trend to centralize the } \\
\text { processing of accounting data, the solution tasks in multiplayer mode, } \\
\text { transition to paperless operation of computing equipment) }\end{array}$ \\
\hline 5. & $\begin{array}{l}1985- \\
2000\end{array}$ & $\begin{array}{l}\text { Information and } \\
\text { telecommunication } \\
\text { revolution }\end{array}$ & $\begin{array}{l}\text { Telecommunica- } \\
\text { tions, cybernetics, } \\
\text { computer science, } \\
\text { Internet }\end{array}$ & \multirow{2}{*}{$\begin{array}{l}\text { End of 1980's - to the present. NIT (new information technology) - a com- } \\
\text { bination of computing, communications and office equipment. New ways } \\
\text { to input / output the accounting information that are convenient for the } \\
\text { user: with the help of human language; graphic images; handwritten text; } \\
\text { artificial intelligence, closely related to a specific branch of knowledge - } \\
\text { accounting. Switch to the technology of manipulation of knowledge, and } \\
\text { not only of data (Integrated solution of accounting tasks; object-oriented } \\
\text { approach; a wide range of applications; network organization of informa- } \\
\text { tion structures; the predominance of interactive interaction of accounting } \\
\text { staff during the operation of computer technology. Implementation of in- } \\
\text { telligent human-machine interface, systems of support of decision-making } \\
\text { in information and advisory systems) }\end{array}$} \\
\hline 6. & $\begin{array}{l}2015- \\
2025 \\
(?)\end{array}$ & $\begin{array}{l}\text { Hypothetical } \\
\text { post-technological } \\
\text { technological } \\
\text { revolution }\end{array}$ & $\begin{array}{l}\text { Biomedicine, } \\
\text { nanotechnologies, } \\
\text { alternative fuels }\end{array}$ & \\
\hline
\end{tabular}

Source: Developed by the authors on the basis of (Šmihula, 2010; Benko, 2010).

The use of information and communication technologies at enterprises is increasing from year to year, as evidenced by data of the State Statistics Service of Ukraine (State Statistics Service of Ukraine, 2018). Cloud computing services were purchased by $10.5 \%$ of enterprises in 2017, which is 1.1 p.p. higher than in 2016 . Among the services of cloud computing, the financial or accounting applications that were bought by $6.1 \%$ of 
companies were the most in demand; followed by e-mail service $-5.5 \%$ and office software rental $-4.9 \%$. In 2016 the respective shares constituted 5,6\%, 4,9\% and 4,3\% (State Statistics Service of Ukraine, 2018).

Taking into account the data of the International Telecommunication Union (ITU) regarding the development of information and communication technologies, it is advisable to make a worldwide cross-country comparison of the abovementioned indicators, including that of Ukraine (Table 2). Development could be assessed with the use of integral indicator, which includes indicators of three groups: access to information and communication technologies, use of information and communication technologies, skills of work with information and communication technologies (Measuring the Information Society, 2015).

Table 2. The ranking of individual countries according to the Index of Development of Information and Communication Technologies (IDI)

\begin{tabular}{|c|c|c|c|c|}
\hline Economy & Rank & IDI & Rank & 2010 \\
2015 & 2015 & 1 & 2010 \\
\hline South Korea & 1 & 8,93 & 4 & 8,64 \\
\hline Denmark & 2 & 8,88 & 3 & 8,18 \\
\hline Iceland & 3 & 8,86 & 10 & 7,19 \\
\hline The United Kingdom & 4 & 8,75 & 8 & 8,43 \\
\hline Sweden & 5 & 8,67 & 12 & 7,82 \\
\hline Luxembourg & 6 & 8,59 & 7 & 7,60 \\
\hline Switzerland & 7 & 8,56 & 13 & 7,82 \\
\hline Netherlands & 8 & 8,53 & 5 & 7,41 \\
\hline Hong Kong, China & 9 & 8,52 & 9 & 8,16 \\
\hline Norway & 10 & 8,49 & 16 & 7,73 \\
\hline Japan & 11 & 8,47 & 50 & 7,30 \\
\hline The USA & 15 & 8,19 & 32 & 5,30 \\
\hline Belarus & 36 & 7,18 & 46 & 6,38 \\
\hline Poland & 44 & 6,91 & 74 & 5,57 \\
\hline The Russian Federation & 45 & 6,91 & 85 & 4,28 \\
\hline Moldova & 66 & 5,81 & 69 & 3,76 \\
\hline Georgia & 78 & 5,25 & 156 & 4,41 \\
\hline Ukraine & 79 & 5,23 & 166 & 1,37 \\
\hline Afghanistan & 156 & 1,83 & & 0,88 \\
\hline Chad & 167 & 1,17 & & \\
\hline
\end{tabular}

Source: International Telecommunication Union, 2015

Regarding the Ukraine, although the ICT development index increased in 2015 compared to 2010, its ranking among 167 other countries of the world declined by 10 units to the level of 79 , indicating a backlog of achievements in the area.

Taking into account the features of the sixth technological cycle, it is appropriate to provide the justification for the introduction of new accounting principles and functions, which are based on the current trends in the development of the new generation of accounting information systems. The latter imply significant changes in the methodology and organization of accounting of the economic entity. An important part of the theoretical grounds of the accounting system are the principles it is build upon. It should be noted that the principle, from a scientific point of view, is a rule that is not violated under any circumstances, it also forms qualitative characteristics of information during its formation to achieve the goal (Mazina, 2013). At the same time, according to the definition of $\mathrm{NP}(\mathrm{C}) \mathrm{BO} 1$, the principle is a rule that should be used while measuring, evaluating and registering business transactions and reflecting their results in financial statements (National Accounting Standard 1, 2013). 
According to the practice of developing an accounting and reporting system, which is based on international standards and on the national system of accounting and reporting, due to changing business conditions as a result of deepening globalization processes and the development of information technologies, the list of fundamental assumptions (principles) also changes (Conceptual basis of financial reporting, 2010).

The development of the accounting system is increasingly directed at the creative professional judgment of experts, while the system of a polyvariative approach to the choice of one or another method of information representation exists and is assumed there. Such an approach to the choice of accounting estimates is possible thanks to the presence of highly intelligent tools, more precisely of modern information systems. Thus, the system itself assumes the existence of such principles as multi-versatility and creativity needed for its operation in order to provide interested users with information for their economic decisions, in addition to legislatively determined accounting and reporting principles (Table 3). The impact of new generation of information systems and accounting technologies on the existing accounting principles is described in Table 3.

Table 3. Critical assessment of existing accounting principles

\begin{tabular}{|c|c|l|}
\hline $\begin{array}{c}\text { No } \\
\text { 3/ח }\end{array}$ & Principle & \multicolumn{1}{|c|}{ Influence of new generation of information systems and accounting technologies } \\
\hline 1. & $\begin{array}{c}\text { Full } \\
\text { coverage }\end{array}$ & $\begin{array}{l}\text { Allow conducting accounting, control and analysis in the real time of operations' reflection, which makes } \\
\text { it possible to create timely and relevant information about business processes necessary for making } \\
\text { management decisions. }\end{array}$ \\
\hline 2. & Autonomy & $\begin{array}{l}\text { Foresee the use of directories and templates of typical business operations, which allows monitoring the } \\
\text { functioning of a legal entity separately from that of its owners }\end{array}$ \\
\hline 3. & Sequences & $\begin{array}{l}\text { Enable modeling the basic approaches to formulating the main principles of the accounting policy for their } \\
\text { constant application and allow changing it in specific cases }\end{array}$ \\
\hline 5. & $\begin{array}{l}\text { Continuity } \\
\text { of the essence } \\
\text { over the form }\end{array}$ & $\begin{array}{l}\text { Allow creating databases on previous reporting periods, which makes it possible to simplify access to } \\
\text { archive information related to the financial and economic activity of the enterprise at any moment, as well as } \\
\text { to determine the current financial and economic state of the enterprise and to predict the future one }\end{array}$ \\
\hline 6. & $\begin{array}{l}\text { Uniform } \\
\text { monetary meter } \\
\text { accounting judgments, which goes beyond the legislation in force, to meet the management's requirements } \\
\text { for the goal of managerial decision-making. }\end{array}$ & $\begin{array}{l}\text { Enable accounting both within the national currency and simultaneously conducting business operations of } \\
\text { the enterprise in the currency of other States (taking into account the exchange rate differences in real time) }\end{array}$ \\
\hline 7. & Charges & $\begin{array}{l}\text { Allows reflecting income and expenditures in accounting and financial reporting at the moment they arise, } \\
\text { regardless the date of receipt or cash payment (in real time) }\end{array}$ \\
\hline 8. & $\begin{array}{l}\text { Other } \\
\text { Principles }\end{array}$ & $\begin{array}{l}\text { Allow accounting based on the principles prescribed by international or national accounting standards } \\
\text { (accounting standards) or by national accounting standards (public accounting standards) in the public } \\
\text { sector, depending on which of the them are applied by the enterprise }\end{array}$ \\
\hline
\end{tabular}

Source: Developed by the authors on the basis of (Law of Ukraine "On Accounting and Financial Reporting in Ukraine", 1999)

Accounting as a system generates and translates information about a particular economic entity for the purpose of decision-making in the conditions of the choice of alternative uses of limited resources. Here one more problem arises- the functioning of the accounting system, which would ensure the achievement of the goals of sustainable development both of the enterprise and of the economy as a whole. The activity of the economic entity in the conditions of technological changes implies the need for management system optimization and accounting improvement. A solid, continuous, documentary display of interconnected economic transactions in monetary terms, their registration and generalization, allow us formulating complete and reliable information about the enterprise (organization) necessary for the decision-making at all levels of management, for assessing the behavior of the enterprise on the market, for revealing the financial state of competitors, attracting investments, assessing expediency of introduction of new technologies and software products to expand the functionality of accounting, for the solution of other tasks. Reliable, timely, substantiated information is a prerequisite for a qualitative analysis of the economic entity and for identifying ways to increase its market value.

In the conditions of technological change, the accounting methodology itself is an important direction of influence on accounting. Nowadays, the Law of Ukraine "On Accounting and Financial Reporting in Ukraine" 
(1999) revises the attitude towards documenting. Thus, it is allowed to use electronic document flow, which needs the computer networks use.

The impact of technologies' development on such an element of the method as assessment is also important. In most cases, it is necessary to deeply ground the assessment of accounting objects for their reflection in the accounting and reporting. This substantiation should include the use of statistics and mathematical apparatus. This task is adequately performed by intelligent information technology. Information technology is currently widely used to assess the yield of agricultural products, forest plantations. In particular, the GIS is a relevant and up-to-date software that provides automated collection, processing, storage, display and distribution of spatially-coordinated information, database integration and its operation, foreseeing powerful means of data representing, query results, samples and analytical calculations in a visual cartographic form (Zatscherkovny et al. 2014). The new generation of accounting information systems implies systems of decision-making support and information systems built upon artificial intelligence (Figure 2). At the moment, the signs of the sixth technological way are formed. In accounting, its perspective direction is the introduction of artificial intelligence, which, on the one hand, carries the risks to society, and on the other - it has a number of advantages in case of rational management and planning. Artificial intelligence systems are already used by the largest audit and financial companies with the help of programs and mobile applications for specific calculations and data analysis. Such technologies are used to solve a narrow range of tasks, but the spectrum of their capabilities expands year by year (Oliynyk \& Osmyatchenko, 2018). Artificial intelligence will change the accounting system and automate the accounting of the business processes that are currently engaged in accounting. The work of accounting personnel will shift from performing routine accounting tasks to more creative managerial functions.

Taking into account the abovementioned, the new accounting principle -creativity- is formed, the essence of which: the adaptation of the accounting system of the enterprise and the personnel to the new operating conditions (dynamic changes in information technology) and globalization processes. This approach is also due to the fact that it takes into account the requirements of IFRS to the reasoned professional judgment of the accountant, which, in international practice, prevails over the instructions and recommendations of accounting regulators (IFRS).

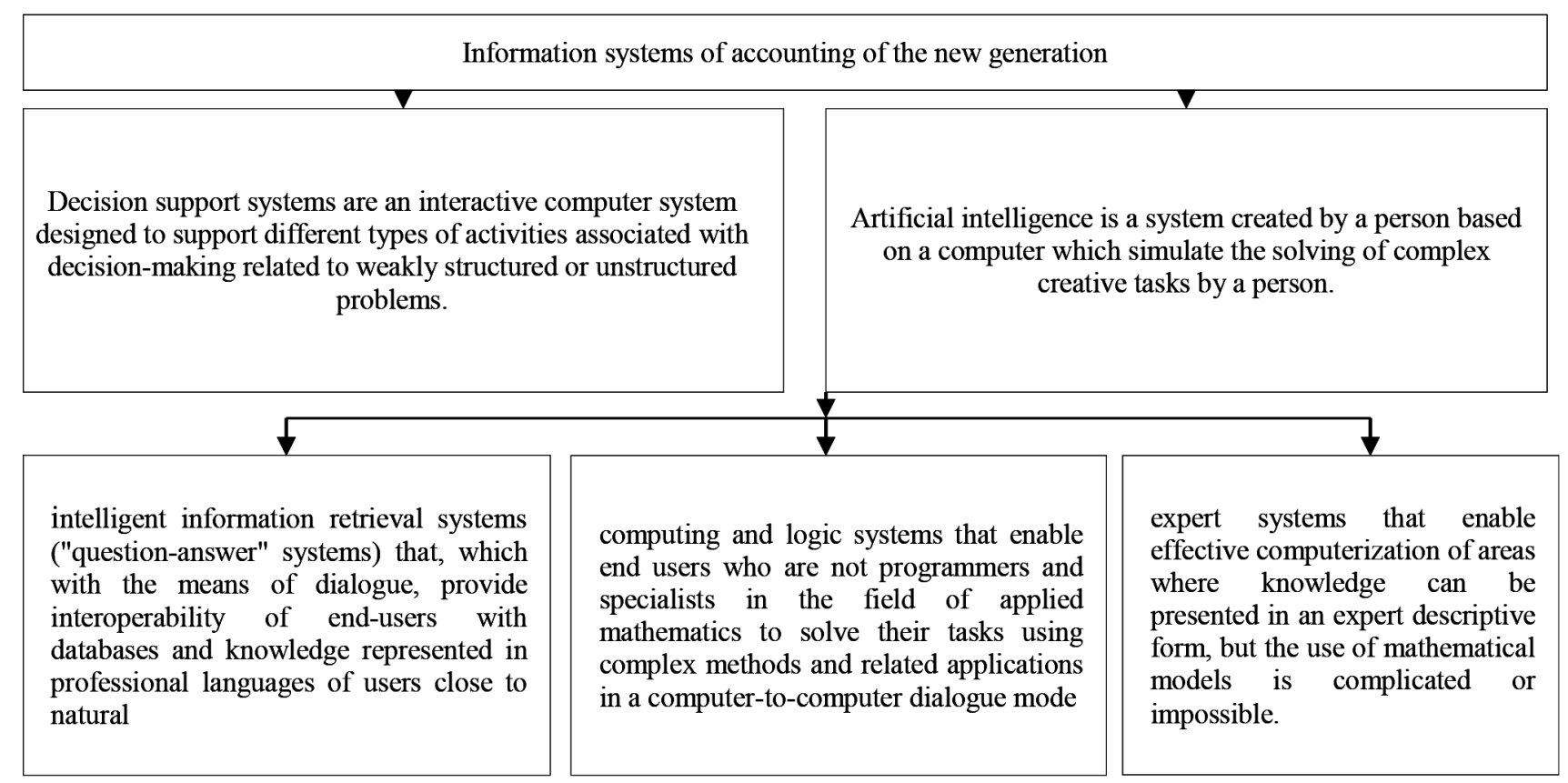

Fig. 2. Information systems of accounting of a new generation

Source: Developed by the authors on the basis of (Benko, 2010) 
Thus: on the one hand, in domestic practice, the accounting rules are rigidly regulated, and on the other - the implementation of international accounting experience, globalization trends, dynamic changes in technologies of various sectors of the economy and in all spheres of human activity, as well as the emergence of new spheres of knowledge, require the flexibility of accounting process and continuous improvement of the professional skills of accountants. All these factors and the use of a professional accountant judgments, which rely on experience and take into account the theoretical grounds and accounting regulations, represent the basis for the formation of the creativity principle in the accounting system, taking into consideration the globalization processes and technological changes, and which will be in line with international practice.

Next, we consider it expedient to highlight the principle of polyvariation, the essence of which is disclosed through the adaptation of accounting information according to the requests of different groups of users which have different goals and tasks. The use of information systems and technologies of the new generation enables the maximum realization of this principle. This principle is based on the concept of multi-variation accounting (Bochulu, 2015).

In the conditions of dynamic changes, the leading position in the accounting belongs to the speed of data processing and the provision of complete, objective, reliable, relevant, necessary information to its users. Thus, the speed of response to technological changes and the introduction of advanced information technologies into accounting practices of domestic enterprises and organizations is the greatest competitive advantage. There is a close relationship between the principles and functions of accounting, which form the prerequisites for the widespread use of information systems and technologies of the new generation. The main goal of these accounting technologies, including cloud and artificial intelligence, is the formation of actual information with the least labor costs, necessary level of detail, which is objective, reliable and timely.

Under the conditions of application of information technologies of a new generation, the strengthening of basic functions is taking place (Fig. 3). In addition, due to the changes in the operation of the information algorithm, there is a need to reinforce the information function by another one - direct connection and the feedback, the essence of which is that the automated accounting system gets information about business operations from the places of their occurrence, checks, processes and transfers it to the automated enterprise management system, then management information is transmitted to the accounting service, which directs this information to the production units and uses it in their work. Thanking to this function, an automated information system is created at the enterprise that provides all levels of management with the necessary data (Osmjchenko, 2014).

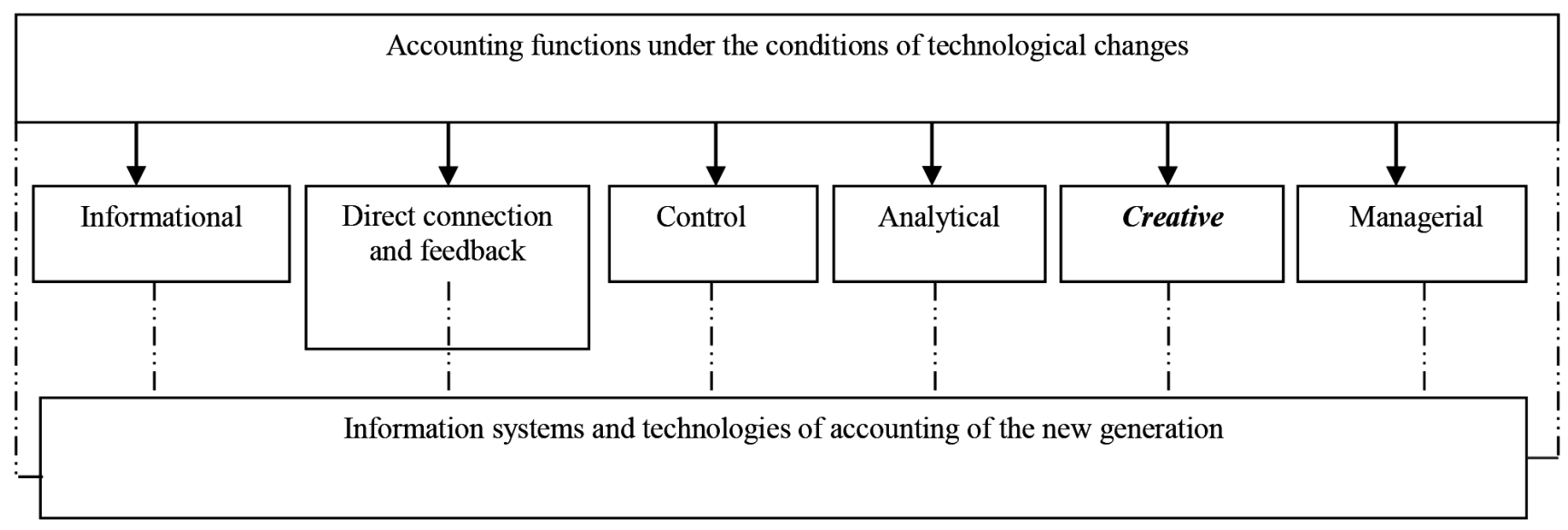

Fig. 3. Functions of accounting under the conditions of technological changes

Source: Developed by the authors

Taking into account the influence of globalization processes, regarding the prospects for implementing artificial intelligence in the accounting process, it is appropriate to introduce a new creative function into the list of accounting functions. The essence of the creative function is revealed in the application of the creative approach 
in the introduction and use of technologies of artificial intelligence in accounting and solving individual tasks in making managerial decisions via the flexible use of the information received.

Information systems and accounting technologies serve as a link between economic activities and managers of all levels of management, who take the decisions.

The data on economic activity is the entry element in the automated system of accounting, while the useful information for managers who make managerial decisions using the creative approach is its output. The process of the accounting functions of direct connection and feedback and the creative function is illustrated on the Fig. 4.

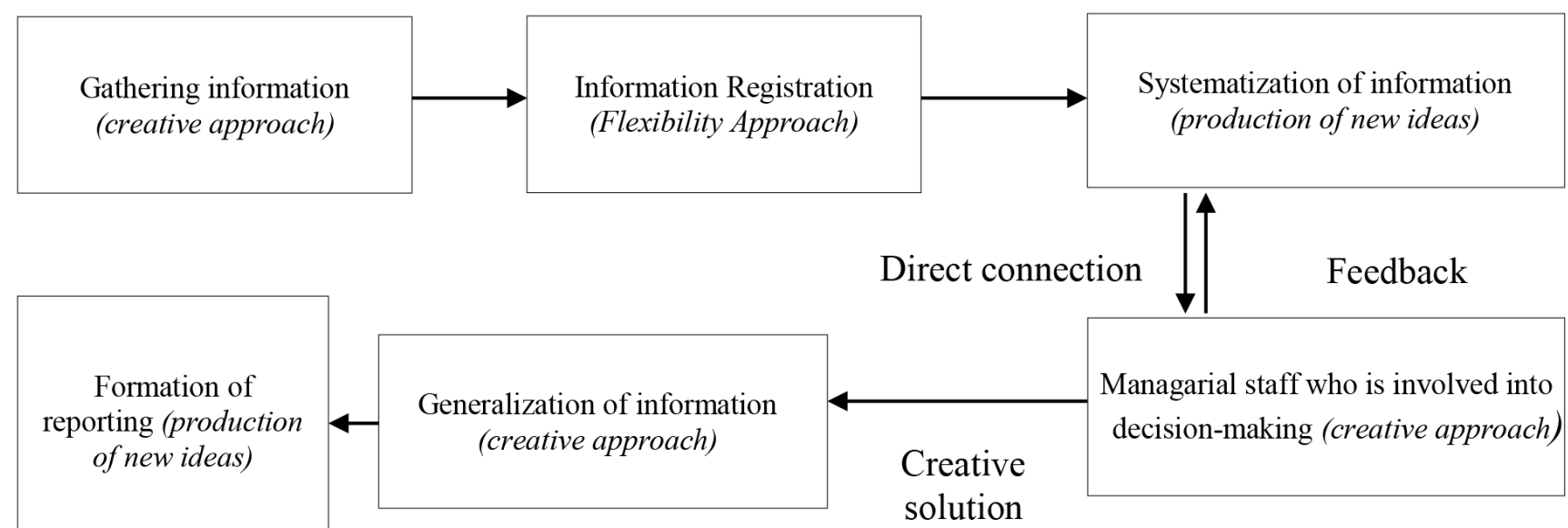

Fig. 4. The process of direct and indirect accounting functions and creative function

Source: Developed by the authors

Thus, the function of creativity is implemented at all stages of the accounting process: from the stage of gathering information to the formation of reporting, through the manifestation of its properties. The input data of the accounting process serve as the basis for the formation of the enterprise strategy. The principle of creativity works at the level of management systems and is considered as one of the fundamental today. The definition of the role of the creative accounting as a necessary condition to overcome the entropy of business given by M.S. Pushkar could serve as a confirmation of this, since it generates an original set of economic indicators describing business activities, provides an opportunity to find solutions aimed at achieving competitive advantages by diagnosing their strengths and weaknesses, by in-depth study of those objects that are not are considered in financial and managerial accounting.

The role of creative accounting for a society is equally important. It is aimed at expanding the arsenal of methods for generating information resources about objects whose existence was acknowledged, but the analysis was not conducted within the enterprise, industry or State as a whole (Pushkar, 2014). Therefore, creativity is the intellectualization of information systems of accounting. In the conditions of globalization, to form the strategy of any enterprise and to implement it effectively, it is undeniable to use modern global information resources, which are obtained with the use of modern information technologies with a strong intellectual potential. The intellectual cycle of the formation and implementation of the enterprise strategy is illustrated on the Fig. 5.

The technological resources of the global level include the latest scientific and technological achievements, in particular, a set of knowledge about the introduction or improvement of equipment needed for the production, patents, licenses, trademarks, technical services in the field of management techniques and marketing know-how.

The local technological resources are the capacities of modern technologies of the enterprise, which can facilitate the exchange of information during the work on projects, ensure the implementation of the overall business strategy, improve planning efficiency, establish interaction with the target audience and strengthen control over financial costs. 
Global information resources include mass media, libraries, and the Internet. At the local level, there are restrictive information resources, among which there are the principles predetermined by law and accounting principles of the level of management systems. At each of the stages of this cycle, the function of creativity is traced.

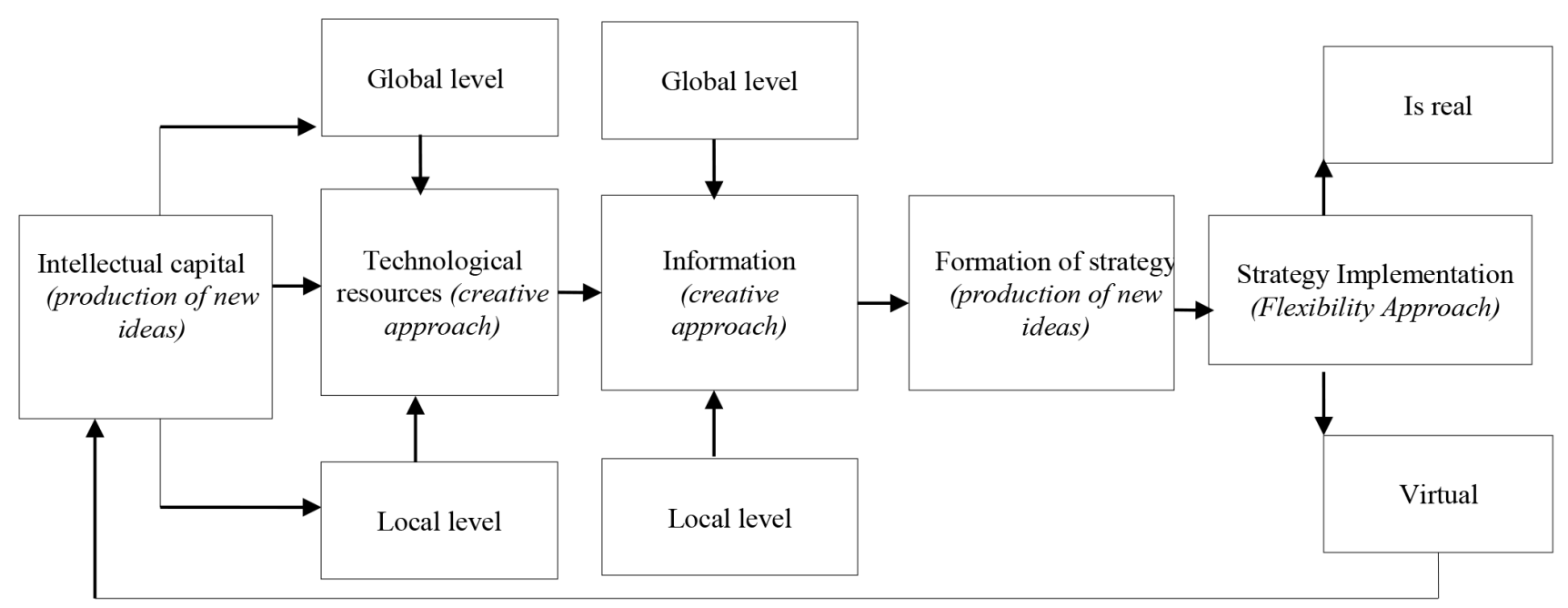

Fig. 5. Intellectual cycle of formation and realization of the strategy of the enterprise

Source: Developed by the authors

Intellectual cycle of strategy formation involves global and internal resources of the enterprise. After the choice of the best virtually implemented strategy, the next step is its realization. There is a possible option when the real implementation of the strategy occurs immediately. Thus, modern technological changes extend the principles and functions of accounting, according to which the formation and implementation of the best version of the strategy of the company takes place.

\section{Conclusions}

1. Globalization processes constant dynamic changes, the emergence of new spheres of knowledge, the development of information systems and accounting technologies require the transformation of its theoretical grounds.

2. According to the results of the critical assessment of existing accounting principles under the influence of information technologies of the new generation, the two groups of them can be distinguished: traditional principles and principles of new generation, the peculiarity of which is the consideration of globalization processes and the adaptation of the accounting system to new dynamic conditions of operation and to the requests of different groups of users.

3. Taking into account the features of the sixth technological way, in the sphere of accounting, the formation of a new accounting principle - creativity- would be correct. Its essence is the adaptation of the accounting system of the enterprise and its personnel to the new conditions of functioning and to globalization processes. In other words, this principle represents the intellectualization of information systems of accounting.

4. In the conditions of technological changes, accounting requires a creative approach and flexibility of accounting staff while introducing and using the information systems and technologies of new generation in order to form timely and reliable information necessary for managerial decision- making and increasing the cost of the economic entity.

5. In practice of the enterprise, the input data of the accounting process serve as the basis for its strategy. In the course of the intellectual cycle of the formation and implementation of the strategy, the global and internal resources of the enterprise are involved; they are combined with the means of the creative approach of personnel and modern information technologies in order to implement the best option. 
In conditions of technological changes and the use of cloud technologies and artificial intelligence future scientific researches should focus on the critical revision of the elements of the accounting method.

\section{References}

Benko, M.M. (2010). Information systems and technologies in accounting. Kyiv: Kyiv National University of Trade and Economics (in Ukrainian)

Bochulia, T.V. (2014). Innovative development of accounting and analytical support of enterprise management. Kharkiv: PH "INZHEK" (in Ukrainian).

Conceptual basis of financial reporting (2010). http://zakon.rada.gov.ua/laws/show/929_009 (in Ukrainian).

Faye Chua (2013). Faye Chua Technology trends: their impact on the global accountancy profession. http://www.accaglobal.com/my/en/ technical-activities/technical-resources-search/2013/may/technologytrends.html

Hlazev, S.Yu. (1993). Theory of long-term technical and economic development. Moscow: VlaDar (in Russian).

Ierokhin, Ye. (2006). Technological styles, dynamics of civilization structures and economic prospect for Ukraine. Economic AnnalsXXI. http://soskin.info/ea/2006/1-2/20060102.html (in Ukrainian).

International Financial Reporting Standards. Retrived from https://www.ifrs.org/issued-standards/list-of-standards/

International Telecommunication Union. (2015). Measuring the Information Society Report 2015. Executive summary. https://www.itu. int/dms_pub/itu-d/opb/ind/D-IND-ICTOI-2015-SUM-PDF-E.pdf

Isniawati, A., Rahmawati, R., \& Gunardi, A. (2018). Information asymmetry and accounting conservatism: Does analyst coverage moderate the results?. Journal of International Studies, 11(3), 176-190. https://doi.org/10.14254/2071-8330.2018/11-3/15

Law of Ukraine dated 16.07.1999 No. 996-XIV “On Accounting and Financial Reporting in Ukraine” (1999). http://zakon.rada.gov.ua/ laws/show/996-14 (in Ukrainian).

Liakhovych, H.I. (2017). Trends in the development of organization of accounting. Herald of ZhSTU. Series: Economic Sciences, 4(82), 42-47. https://doi.org/10.26642/jen-2017-4(82)-42-47 (in Ukrainian).

Limba T., Stankevičius A., Andrulevičius A. (2018). Industry 4.0 and national security: the phenomenon of disruptive technology. Entrepreneurship and Sustainability Issues, 6(3), 1328-1335. https://doi.org/10.9770/jssi.2019.6.3(33)

Mazina, O.I. (2013). Formation of management reporting concepts. Accounting and auditing, 9, 10-16 (in Ukrainian).

Measuring the Information Society (2015). Report 2015 - Executive Summary. https://www.itu.int/en/ITU-D/Statistics/Documents/publications/misr2015/MISR2015-ES-R.pdf (in Russian)

National Accounting Standard 1 “General Requirements to Financial Statements” (2013). http://zakon.rada.gov.ua/laws/show/z0336-13 (in Ukrainian).

Oliinyk, V.S., \& Osmiatchenko, V.O. (2018). Status and prospects of accounting development in the context of the change of waves of innovation. Economic Herald. Series: Finance, Accounting, Taxation, 2, 131-138 (in Ukrainian).

Osmiatchenko, V.O. (2014). The Influence of Information Technologies on the Principles and Functions of Accounting. Socio-economic problems and the state, 1(10), 80-87 (in Ukrainian).

Paiva, I., \& Carvalho, L. (2018). Accounting and Management Practices in the Third Sector in Angola. Economics and Sociology, 11(3), 28-42. https://doi.org/10.14254/2071-789X.2018/11-3/2

Pushkar, M.S. (2014). Creative accounting is a benefit for business and society. http://dspace.tneu.edu.ua/bitstream/316497/16096/1/36-39. pdf (in Ukrainian).

Pustylnick, I., Temchenko, O., \& Gubarkov, S. (2017). Estimating the influence of accounting variables change on earnings management detection. Journal of International Studies, 10(1), 110-122. https://doi.org/10.14254/2071-8330.2017/10-1/7

State Statistics Service of Ukraine (2018). The use of information and communication technologies at enterprises in 2017. http://www. ukrstat.gov.ua/express/expr2018/05/82.pdf (in Ukrainian)

Zatserkovnyi, V.I., Burachek, V.H., Zhelezniak, O.O., \& Tereshchenko, A.O. (2014). Geographic information systems and databases. Nizhyn: NSU named after Nikolai Gogol (in Ukrainian). 
Zuchewicz, J. (2015). Wspyiczesne determinanty rozwoju rachunkowoњci [Contemporary determinants of accountancy development]. Prace Naukowe Uniwersytetu Ekonomicznego we Wrociawiu. Teoria rachunkowosci, sprawozdawczosci i analiza finansowa, 388, 189197.

Zhatkin, Y., Gurvitš, N., Strouhal, J. (2017). Addressing Ethical Matters in Ukrainian Accounting Practice. Economics and Sociology, 10(3), 167-178. https://doi.org/10.14254/2071-789X.2017/10-3/12

Šmihula, D. (2010). Waves of technological innovations and the end of the information revolution. J. Economics and International Finance, 2(4), 58-67.

Vegera, S., Malei, A., Sapeha, I., Sushko, V. (2018). Information support of the circular economy: the objects of accounting at recycling technological cycle stages of industrial waste. Entrepreneurship and Sustainability Issues, 6(1), 190-210. http://doi.org/10.9770/ jesi.2018.6.1(13) 